[Regular Paper]

\title{
Direct Decomposition of NO over Supported-alkaline Earth Metal Oxide Catalysts
}

\author{
Goro TsUBOI $^{\dagger 2)}$, Masaaki HANEDA ${ }^{\dagger 1 *}$, Yukinori NAGAO ${ }^{\dagger 2}$, Yoshiaki KINTAICHI $^{\dagger 1)}$, and Hideaki HAMADA ${ }^{\dagger 1)}$ \\ ${ }^{\dagger 1)}$ Research Institute for Innovation in Sustainable Chemistry, National Institute of Advanced Industrial Science and Technology, \\ AIST Tsukuba Central 5, 1-1-1 Higashi, Tsukuba, Ibaraki 305-8565, JAPAN \\ ${ }^{\dagger 2}$ Faculty of Science and Technology, Tokyo University of Science, 2641 Yamazaki, Noda, Chiba 278-8510, JAPAN
}

(Received July 28, 2004)

\begin{abstract}
NO decomposition over supported alkaline earth metal oxide catalysts was strongly dependent on the type of metal oxide support. $\mathrm{Y}_{2} \mathrm{O}_{3}$ was the most effective support. $\mathrm{Ba} / \mathrm{Y}_{2} \mathrm{O}_{3}$ showed the highest $\mathrm{NO}$ decomposition activity, which decreased in the order of $\mathrm{Ba} / \mathrm{Y}_{2} \mathrm{O}_{3}>\mathrm{Sr} / \mathrm{Y}_{2} \mathrm{O}_{3}>\mathrm{Ca} / \mathrm{Y}_{2} \mathrm{O}_{3}>\mathrm{Mg} / \mathrm{Y}_{2} \mathrm{O}_{3} \sim \mathrm{Y}_{2} \mathrm{O}_{3}$. The catalytic activity of $\mathrm{Ba} / \mathrm{Y}_{2} \mathrm{O}_{3}$ for $\mathrm{NO}$ decomposition at $900^{\circ} \mathrm{C}$ gradually increased with reaction time. The activity enhancement was due to the decomposition of barium carbonate into barium oxide during the reaction. Barium carbonate was completely decomposed by reduction with $\mathrm{H}_{2}$ at $900^{\circ} \mathrm{C}$, resulting in significant enhancement of $\mathrm{NO}$ decomposition activity. The activity of $\mathrm{Ba} / \mathrm{Y}_{2} \mathrm{O}_{3}$ increased with higher barium loading up to $5 \mathrm{wt} \%$, and then became constant. There was a strong relationship between $\mathrm{NO}$ conversion and the amount of $\mathrm{NO}$ adsorption on $\mathrm{Ba} / \mathrm{Y}_{2} \mathrm{O}_{3}$, suggesting that $\mathrm{NO}$ adsorption sites are the reaction sites for $\mathrm{NO}$ decomposition. The relationship between the activity for 1-butene isomerization, which is an indicator for the basicity of $\mathrm{Ba} / \mathrm{Y}_{2} \mathrm{O}_{3}$ catalysts, and the activity for NO decomposition suggests direct participation of basic sites in the NO decomposition reaction over supported alkaline earth metal oxide catalysts.
\end{abstract}

\section{Keywords}

Nitrogen monoxide, Direct decomposition, Alkaline earth metal catalyst, Yttrium oxide support, Basic site

\begin{abstract}
1. 緒言
ボイラーやエンジンから排出される窒素酸化物 $\left(\mathrm{NO}_{x}\right)$ は, 人体に有害で酸性雨の原因ともなっている大気污染物質であ る。これまでにガソリン自動車においては三元触媒法が，ボイ ラーなどの大型固定発生源にはアンモニア選択還元法が既に実 用化されている。最近，ディーゼルやリーンバーンエンジン排 ガス中の $\mathrm{NO}_{x}$ 除去触媒技術として, 炭化水素類や水素, 一酸化 炭素などによる $\mathrm{NO}$ 選択還元反応が注目されている。以上の方 法はすべて, $\mathrm{NO}$ を還元剤と反応させることで $\mathrm{N}_{2}$ へ還元する接 触還元法に分類される。

一方, 還元法とは別に $\mathrm{NO}$ を直接 $\mathrm{N}_{2}$ と $\mathrm{O}_{2}$ へと分解する $\mathrm{NO}$ 直 接分解法がある。この反応は還元剤が不要で, 全ての $\mathrm{NO}_{x}$ 排出 源に適用できる最も理想的な $\mathrm{NO}_{x}$ 除去方法である。 $\mathrm{NO}$ 直接分 解反応は熱力学的には $1000^{\circ} \mathrm{C}$ 以下の温度で十分に進行する反 応であるが， N-O間の結合エネルギーは極めて大きく, 速度論 的にはNOは非常に安定な物質である。したがって, 触媒の利 用が有効であると期待される。実際，これまでに，貴金属， 金属酸化物 ${ }^{2)}$, ペロブスカイト ${ }^{3)}$ ，銅イオン交換ゼオライト4) ど多くの触媒上で $\mathrm{NO}$ 直接分解反応が進行することが報告され
\end{abstract}

* To whom correspondence should be addressed.

* E-mail: m.haneda@aist.go.jp
ている。金属酸化物の中では酸化コバルトが最も高い活性を示 すことが知られているが5), 最近, 我々は, 酸化コバルト自体 のNO分解活性はほとんどないこと, 酸化コバルトに微量のア ルカリやアルカリ土類を添加すると大幅に NO分解活性が向上 すること, 添加したアルカリやアルカリ土類上でNO分解反応 が進行することを明らかにしだ,7)。一般にアルカリやアルカ リ土類は塩基性触媒として作用することが知られており, NO 直接分解反応においても触媒の塩基点が重要な役割を担ってい ることが推定される。

本研究では上記の仮説を検証することを目的として, 塩基性 酸化物として担持アルカリ土類酸化物について詳細な検討を 行った。単独のアルカリ土類酸化物の NO分解活性はMeubus ${ }^{8)}$ によって $\mathrm{BaO}>\mathrm{SrO}>\mathrm{CaO}$ の順で低下することが最初に報告さ れた。また担持アルカリ土類酸化物では, Vannice ら ${ }^{9,10)}$ やXie ら 11$)$ にって $\mathrm{Sr} / \mathrm{La}_{2} \mathrm{O}_{3}$ や $\mathrm{Sr} / \mathrm{Sm}_{2} \mathrm{O}_{3}, \mathrm{Ba} / \mathrm{MgO}$ が $\mathrm{NO}$ 分解活性を 示すことが報告されている。しかしながら, いずれも触媒の塩 基性と NO分解活性の相関性については全く検討されていな い。本研究においては, 担持アルカリ土類酸化物触媒の NO分 解特性と触媒の塩基性との相関性について詳細に検討したの で，その結果を報告する。 
Table 1 BET Surface Area of and NO Conversion on Metal Oxide and Supported Alkaline Earth Metal Oxide (10.9 wt\%) Catalysts for NO Decomposition

\begin{tabular}{|c|c|c|c|c|c|c|}
\hline & \multirow{2}{*}{$\begin{array}{l}\text { BET surface } \\
\text { area }\left[\mathrm{m}^{2} \cdot \mathrm{g}^{-1}\right]\end{array}$} & \multicolumn{5}{|c|}{$\mathrm{NO}$ conversion to $\mathrm{N}_{2}[\%]$} \\
\hline & & $700^{\circ} \mathrm{C}$ & $750^{\circ} \mathrm{C}$ & $800^{\circ} \mathrm{C}$ & $850^{\circ} \mathrm{C}$ & $900^{\circ} \mathrm{C}$ \\
\hline $\mathrm{Y}_{2} \mathrm{O}_{3}$ & 18.9 & 2.7 & 3.4 & 4.7 & 7.0 & 8.7 \\
\hline $\mathrm{MgO}$ & 32.0 & $\leq 1$ & $\leq 1$ & $\leq 1$ & $\leq 1$ & $\leq 1$ \\
\hline $\mathrm{La}_{2} \mathrm{O}_{3}$ & 7.5 & $\leq 1$ & $\leq 1$ & $\leq 1$ & 1.8 & 3.5 \\
\hline $\mathrm{Sm}_{2} \mathrm{O}_{3}$ & 8.0 & 2.8 & 4.7 & 7.2 & 10.8 & 13.9 \\
\hline $\mathrm{Al}_{2} \mathrm{O}_{3}$ & 190 & $\leq 1$ & $\leq 1$ & $\leq 1$ & $\leq 1$ & $\leq 1$ \\
\hline $\mathrm{SiO}_{2}$ & 286 & $\leq 1$ & $\leq 1$ & $\leq 1$ & $\leq 1$ & $\leq 1$ \\
\hline $\mathrm{Ba} / \mathrm{Y}_{2} \mathrm{O}_{3}$ & 13.8 & 4.4 & 7.6 & 15.7 & 21.1 & 41.0 \\
\hline $\mathrm{Ba} / \mathrm{MgO}$ & 9.4 & 8.4 & 11.0 & 12.2 & 13.0 & 35.5 \\
\hline $\mathrm{Ba} / \mathrm{La}^{2} \mathrm{O}_{3}$ & 6.4 & $\leq 1$ & $\leq 1$ & $\leq 1$ & 1.7 & 21.5 \\
\hline $\mathrm{Ba} / \mathrm{Sm}_{2} \mathrm{O}_{3}$ & 12.8 & 5.6 & 7.1 & 14.5 & 13.6 & 36.1 \\
\hline $\mathrm{Ba} / \mathrm{Al}_{2} \mathrm{O}_{3}$ & 170 & $\leq 1$ & $\leq 1$ & $\leq 1$ & $\leq 1$ & $\leq 1$ \\
\hline $\mathrm{Ba} / \mathrm{SiO}_{2}$ & 144 & $\leq 1$ & $\leq 1$ & $\leq 1$ & $\leq 1$ & $\leq 1$ \\
\hline $\mathrm{Mg} / \mathrm{Y}_{2} \mathrm{O}_{3}$ & & 2.2 & 3.7 & 4.6 & 6.4 & 7.6 \\
\hline $\mathrm{Ca} / \mathrm{Y}_{2} \mathrm{O}_{3}$ & & 2.8 & 4.5 & 6.6 & 10.7 & 15.1 \\
\hline $\mathrm{Sr} / \mathrm{Y}_{2} \mathrm{O}_{3}$ & 15.9 & 2.0 & 2.9 & 3.4 & 4.3 & 26.4 \\
\hline
\end{tabular}

Reaction conditions: $\mathrm{NO}=1000 \mathrm{ppm}, W / F=0.5 \mathrm{~g} \cdot \mathrm{s} \cdot \mathrm{cm}^{-3}$.

" $\leq 1$ " means the values below identification limit by GC.

\section{2. 実験}

\section{1. 触媒調製}

金属酸化物担体 $\left(\mathrm{Y}_{2} \mathrm{O}_{3}, \mathrm{La}_{2} \mathrm{O}_{3}, \mathrm{Sm}_{2} \mathrm{O}_{3}\right)$ は，各金属の硝酸 塩水溶液 $(0.4 \mathrm{~mol} / l)$ にその 1.2 倍当量の炭酸アンモニウム水 溶液をゆっくりと滴下することにより沈殿を生成させ，この沈 殿を洗浄，乾燥後，空気気流中 $400^{\circ} \mathrm{C}$ で 4 時間焼成することに より調製した。上記の金属酸化物のほかに, $\mathrm{SiO}_{2}$ （富士シリシ ア化学, Cariact G-10), $\mathrm{Al}_{2} \mathrm{O}_{3}$ (水澤化学工業, GB-45), $\mathrm{MgO}$ （触媒学会参照触媒 JRC-MGO4-500A）も担体として使用した。 担持アルカリ土類酸化物触媒は，所定濃度のアルカリ土類金属 $(\mathrm{Mg}, \mathrm{Ca}, \mathrm{Sr}, \mathrm{Ba})$ 硝酸塩水溶液を金属酸化物担体に含浸後, 乾燥・空気気流中 $700^{\circ} \mathrm{C}$ で 5 時間焼成することにより調製した。 アルカリ土類金属の担持量は，金属換算でバリウムは 1 17 $\mathrm{wt} \%$ ，それ以外は $10.9 \mathrm{wt} \%$ とした。

\subsection{NO直接分解反応}

$\mathrm{NO}$ 直接分解反応は固定床流通反応装置を用い, $1000 \mathrm{ppm}$ $\mathrm{NO}$ を含むへリウム希橎の反応ガスを $30 \mathrm{~cm}^{3} \cdot \mathrm{min}^{-1}$ のガス流速 で触媒 $(0.25 \mathrm{~g})$ 上に流通して行った。ガス成分の分析は，ガ スクロマトグラフ（島津製作所，GC-8A）2台と化学発光式 $\mathrm{NO}_{x}$ 分析計（島津製作所，NOA-305A）を用いて行った。反応 ガスの定量は， $\mathrm{N}_{2} ， \mathrm{O}_{2}$ （カラム: モレキュラーシーブ5A）およ び $\mathrm{N}_{2} \mathrm{O}$ （カラム: ポラパック Q）について行い, 触媒活性は NO の $\mathrm{N}_{2}$ への転化率で評価した。なお，ここで検討した触媒では $\mathrm{N}_{2} \mathrm{O}$ の生成はほとんど認められなかった。

\section{3. 触媒のキャラクタリゼーション}

触媒のキャラクタリゼーションとして, 簡易型流通式表面積 測定装置（Micromeritics Flowsorb II 2300）によるBET 比表面積 測定，粉末 X線回折（XRD: X-ray diffraction, Mac Science, $\left.\mathrm{M} 18 \mathrm{XHF}^{22}\right)$ による結晶構造の同定，パルス法によるNO吸着 量の測定およびFT-IRによる吸着 $\mathrm{NO}_{x}$ 種の観察を行った。パル
ス法による NO吸着量の測定は, 所定量の触媒（0.06 g) をへ リウム気流中, $500^{\circ} \mathrm{C}$ で前処理後, 室温まで冷却し, $\mathrm{NO}$ 吸着 が認められなくなるまでNOパルスを導入することにより行っ た。吸着 $\mathrm{NO}_{x}$ 種の観察は拡散反射型セル（Spectra Tech）を装 備した赤外分光装置（Nicolet， NEXUS 670 FT-IR）を使用して 行った。あらかじめ $900^{\circ} \mathrm{C}$ で水素還元処理を行った触媒試料 $(20 \mathrm{mg})$ をセル内に充填し， $600^{\circ} \mathrm{C}$ で1時間，ヘリウム気流中 で前処理後, $600^{\circ} \mathrm{C}$ で $1000 \mathrm{ppm} \mathrm{NO/He}$ を流通下, IRスペクト ルを測定した。

\subsection{1-ブテン異性化反応}

塩基触媒モデル反応として1-ブテン異性化反応を閉鎖循環系 反応装置を使用して行った。あらかじめ $900^{\circ} \mathrm{C}$ で水素還元処理 を行った触媒 $(0.03 \mathrm{~g})$ をパイレックス製反応管に充填し，前 処理として $450^{\circ} \mathrm{C} て ゙ 1 \times 10^{-3} \mathrm{~Pa}$ の条件で 1 時間, 真空排気処理を 行った。その後, 反応温度 $0^{\circ} \mathrm{C}$ において, $93 \mathrm{kPa}$ の 1-ブテンを 導入して反応を行った。反応ガスを適宜サンプリングし，ガス クロマトグラフ（島津製作所， GC-8A）を用いて1-ブテン， cis-2-ブテン，trans-2-ブテン（カラム: VZ-7）の定量を行った。

\section{3. 結果および考察}

\section{1. 担持アルカリ土類酸化物触媒の NO 分解活性}

まず，担持アルカリ土類酸化物触媒の NO分解活性に及ぼす 担体の影響について検討した。Table 1 には前処理を行ってい ない担持バリウム $(10.9 \mathrm{wt} \%)$ 触媒について測定した結果を示 す。担持バリウム触媒の NO分解活性は反応温度とともに高く なり, 検討した温度範囲に扔いては $900^{\circ} \mathrm{C}$ で最も高い活性が得 られた。またTable 1から明らかなように, 担持バリウム触媒 のNO分解活性は金属酸化物担体に依存している。使用した金 属酸化物の中では $\mathrm{Y}_{2} \mathrm{O}_{3}$ が最も有効な担体であり, $\mathrm{NO}$ 分解活性 は $\mathrm{Ba} / \mathrm{Y}_{2} \mathrm{O}_{3}>\mathrm{Ba} / \mathrm{Sm}_{2} \mathrm{O}_{3}>\mathrm{Ba} / \mathrm{MgO}>\mathrm{Ba} / \mathrm{La}_{2} \mathrm{O}_{3} \gg \mathrm{Ba} / \mathrm{Al}_{2} \mathrm{O}_{3} \sim \mathrm{Ba} / \mathrm{SiO}_{2}$ の順で低下した。Fig. 1 に $\mathrm{Ba} / \mathrm{Y}_{2} \mathrm{O}_{3}$ 触媒上での $\mathrm{NO}$ 分解反応に 


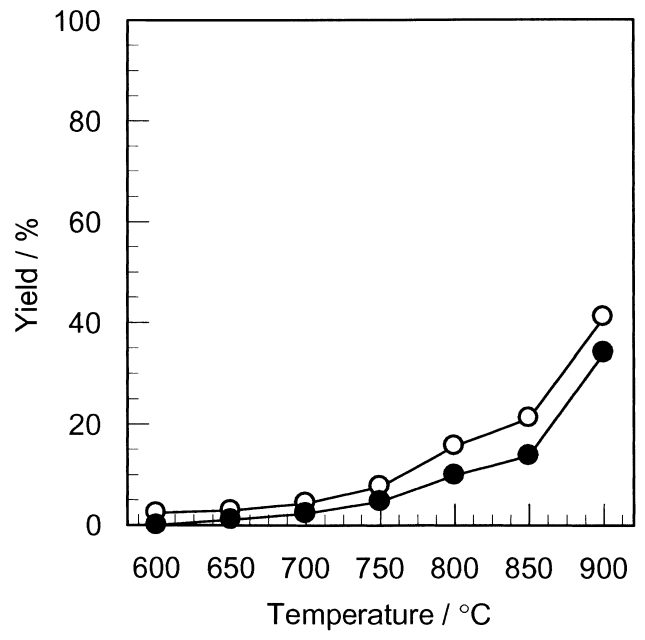

$\bigcirc: \mathrm{N}_{2}$ yield, $\bigcirc: \mathrm{O}_{2}$ yield

Fig. 1 Catalytic Activity of $10.9 \mathrm{wt} \% \quad \mathrm{Ba} / \mathrm{Y}_{2} \mathrm{O}_{3}$ for $\mathrm{NO}$ Decomposition

より生成した $\mathrm{N}_{2}$ と $\mathrm{O}_{2}$ の収率を示す。測定を行った全温度域に おいて $\mathrm{O}_{2}$ の生成が認められ, $\mathrm{NO}$ 直接分解反応が触媒的に進行

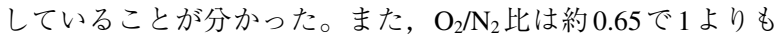
小さくなったが，これは生成した $\mathrm{O}_{2}$ の一部がガスクロマトグ ラフのカラム内でNO と反応してしまったためである。

Table 1には各触媒のBET 比表面積の結果も示すが，NO分 解活性との間に相関性は認められない。また，金属酸化物担体 のみの場合, $\mathrm{Y}_{2} \mathrm{O}_{3}, \mathrm{Sm}_{2} \mathrm{O}_{3}$ および $\mathrm{La}_{2} \mathrm{O}_{3}$ 上では $\mathrm{NO}$ 分解反応が 進行した。これは担体も何らかの形でNO分解反応に関与して いることを示唆する結果であるが，バリウムを担持することで $\mathrm{NO}$ 分解活性が大幅に向上していることから，NO分解反応は 主にバリウム上で進行しているものと推定される。

次に, 最も有効な担体である $\mathrm{Y}_{2} \mathrm{O}_{3}$ に担持したアルカリ土類 酸化物 (10.9 wt\%) 触媒の NO分解活性を評価した。その結果 も Table 1にまとめた。マグネシウムの担持は効果が見られな かったが，カルシウム，ストロンチウム，バリウムの担持によ り $\mathrm{NO}$ 転化率は大きく向上した。検討した触媒の中では $\mathrm{Ba} / \mathrm{Y}_{2} \mathrm{O}_{3}$ が最も高い活性を示し, NO分解活性は $\mathrm{Ba} / \mathrm{Y}_{2} \mathrm{O}_{3}>$ $\mathrm{Sr} / \mathrm{Y}_{2} \mathrm{O}_{3}>\mathrm{Ca} / \mathrm{Y}_{2} \mathrm{O}_{3}>\mathrm{Mg} / \mathrm{Y}_{2} \mathrm{O}_{3} \sim \mathrm{Y}_{2} \mathrm{O}_{3}$ の順で低下した。我々はこ れまでに酸化コバルトへのアルカリ土類の添加効果を検討し, バリウムの添加が最も効果的であること, NO分解活性は担持 されているアルカリ土類の分散性に依存することを明らかにし た7)。 $\mathrm{Y}_{2} \mathrm{O}_{3}$ 担体においても担持されているアルカリ土類の分散 性が重要であることが推測される。以降, 最も高い活性を示し た $\mathrm{Ba} / \mathrm{Y}_{2} \mathrm{O}_{3}$ について詳細に検討した。

\section{2. $\mathrm{Ba} / \mathrm{Y}_{2} \mathrm{O}_{3}$ 触媒の NO 分解活性}

\section{2. 1. 触媒前処理の影響}

Fig. 2 に $\mathrm{Ba} / \mathrm{Y}_{2} \mathrm{O}_{3}$ 触媒の $\mathrm{NO}$ 分解反応の経時变化を示す。反 応温度 $800^{\circ} \mathrm{C}, 850^{\circ} \mathrm{C}$ では温度变化後, 比較的短時間で定常活 性を示した。一方， $900^{\circ} \mathrm{C}$ では反応初期に高い $\mathrm{NO}$ 転化率が得 られたが，その後，徐々に低下した。初期の高いNO転化率が 得られた際の窒素の物質収支は 100\%を大きく超えたころか

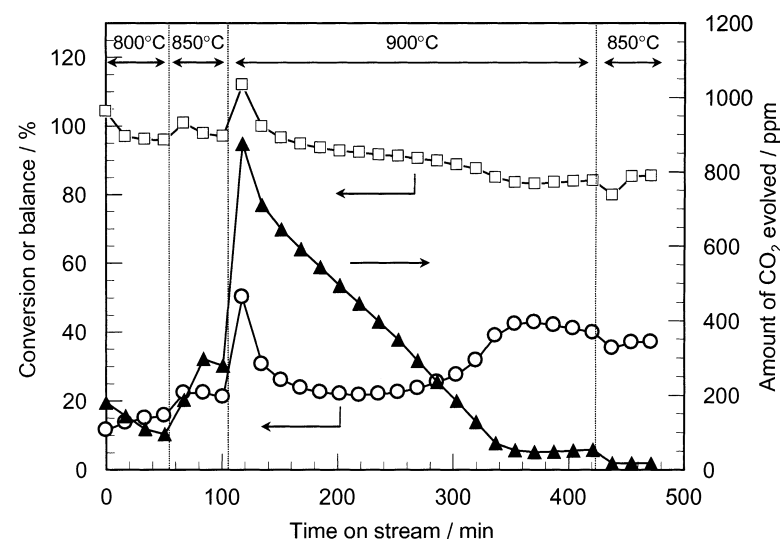

Fig. 2 Time Dependence of the Conversion of $\mathrm{NO}$ to $\mathrm{N}_{2}(\mathrm{O})$, Nitrogen Balance $(\square)$ and Evolution $\mathrm{CO}_{2}(\boldsymbol{\Delta})$ on 10.9 $\mathrm{wt} \% \mathrm{Ba} / \mathrm{Y}_{2} \mathrm{O}_{3}$

ら, $850^{\circ} \mathrm{C}$ 以下で触媒に吸着した $\mathrm{NO}_{x}$ 種の分解により一時的に 高い $\mathrm{NO}$ 転化率が得られたものと考えられる。900 C でさらに 反応を続けると NO転化率は徐々に増加した後, 定常活性を示 した。

Fig. 2 には反応中に触媒から脱離してくる $\mathrm{CO}_{2}$ の量もプロッ トしたが, $\mathrm{CO}_{2}$ 脱離量は反応温度 $900^{\circ} \mathrm{C}$ になると急激に増加し, その後, 反応時間とともに徐々に減少した。これは $\mathrm{Y}_{2} \mathrm{O}_{3}$ 上に 担持されたバリウムは一部炭酸塩の状態で存在しており, $900^{\circ} \mathrm{C}$ では炭酸塩が徐々に熱分解することを示唆している。ま た， $900^{\circ} \mathrm{C}$ での定常活性は $\mathrm{CO}_{2}$ 脱離がほとんど認められなく なった時点で得られたことから, 炭酸塩の分解により NO分解 反応の活性点が生成しているものと推測される。事実, 反応温 度を再度 $850^{\circ} \mathrm{C}$ にして測定した場合, NO転化率は昇温時に測 定した值よりも高くなった $(21 \% \rightarrow 37 \%)$ 。

以上の結果より, $\mathrm{Ba} / \mathrm{Y}_{2} \mathrm{O}_{3}$ 触媒が高い $\mathrm{NO}$ 分解活性を発現す るためには炭酸塩の分解が重要であると考えられる。そこで, この考察を検証するために, 前処理で触媒中に残存する炭酸塩 を分解した後，NO分解活性を評価した。炭酸塩の分解に関す る報告はいくつかあるが，一般に炭酸塩の熱分解は $1000^{\circ} \mathrm{C}$ 以 上の高温でないと起こらない。一方, Huang ら ${ }^{12)}$ は, $\mathrm{La}_{2} \mathrm{O}_{3}$ 表 面に生成した炭酸塩種の除去方法を検討し, $500^{\circ} \mathrm{C}$ 以上で水素 還元処理を行うと容易に炭酸塩種が分解することを報告した。 そこで，本研究に扔いても水素還元処理が有効であると考え， 前処理として $900^{\circ} \mathrm{C}$ で水素還元処理を行った。前処理前後の $\mathrm{Ba} / \mathrm{Y}_{2} \mathrm{O}_{3}$ 触媒の XRD パターンをFig. 3 に示す。前処理前 (7000 C で空気焼成後), 炭酸バリウムに䚻属されるピークが見 られたが，900C での水素還元処理を行うことによりピークは 消失し, $900^{\circ} \mathrm{C}$ で水素還元処理が炭酸バリウムの分解に有効で あることが分かった。また，前処理前に見られた酸化バリウム のピークも消失していることから, $900^{\circ} \mathrm{C}$ での水素還元処理に より酸化バリウム自体も高分散化したものと考えられる。

Fig. 4 には $900^{\circ} \mathrm{C}$ で水素還元処理を行った $\mathrm{Ba} / \mathrm{Y}_{2} \mathrm{O}_{3}$ 触媒と何 も処理を行っていない触媒の $\mathrm{NO}$ 分解活性を示す。明らかに水 素還元処理を行った触媒の方が全温度域で高いNO分解活性を 示して抢り, 触媒に残存する炭酸塩が分解して活性種の酸化物 


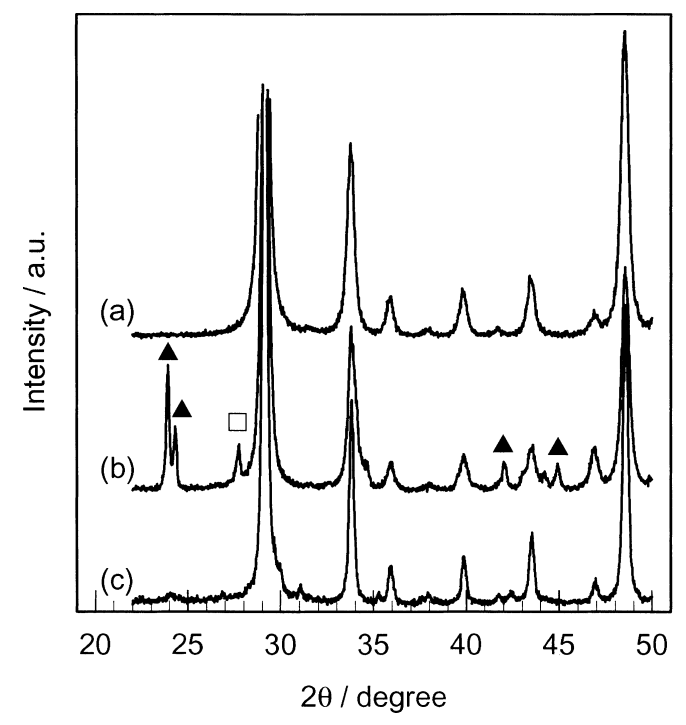

A: $\mathrm{BaCO}_{3}, \square: \mathrm{BaO}$.

Fig. 3 XRD Patterns of (a) $\mathrm{Y}_{2} \mathrm{O}_{3}$ and $10.9 \mathrm{wt} \% \quad \mathrm{Ba} / \mathrm{Y}_{2} \mathrm{O}_{3}$ (b) before and (c) after $\mathrm{H}_{2}$ Reduction at $900^{\circ} \mathrm{C}$

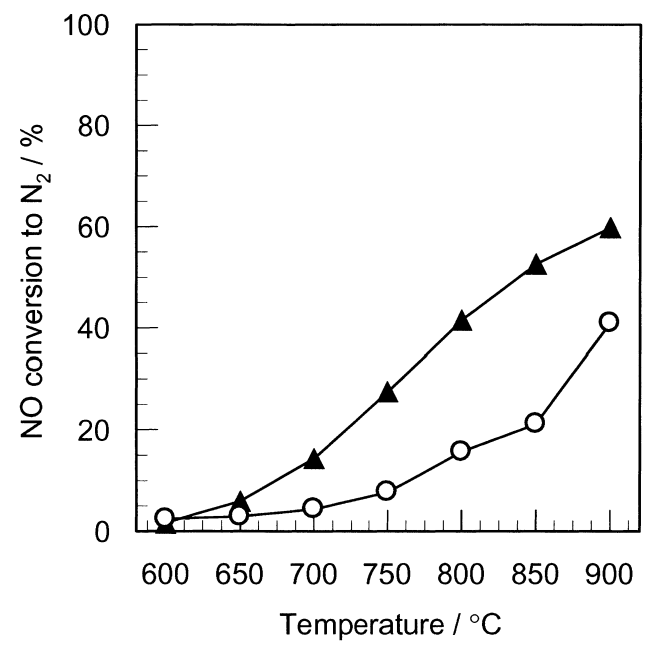

$\bigcirc$ : fresh, $\boldsymbol{\Delta}$ : after $\mathrm{H}_{2}$ reduction at $900^{\circ} \mathrm{C}$. Conditions: $\mathrm{NO}=$ $1000 \mathrm{ppm}, W / F=0.5 \mathrm{~g} \cdot \mathrm{s} \cdot \mathrm{m}^{-3}$.

Fig. 4 Effect of Pretreatment on the Catalytic Activity of 10.9 $\mathrm{wt} \% \mathrm{Ba} / \mathrm{Y}_{2} \mathrm{O}_{3}$ for NO Decomposition

が生成することにより $\mathrm{NO}$ 分解活性が向上したものと考えられ る。900ㄷ での NO転化率も水素還元処理を行った触媒の方が 高くなっているが，これはFig. 2からもわかるように，水素還 元処理を行わないと $900^{\circ} \mathrm{C}$ で長時間反応を行っても炭酸塩の分 解が完全には終了しないためと思われる。以降, NO分解活性 は触媒を $900^{\circ} \mathrm{C}$ で水素還元処理を行った後に評価した。

\subsection{2. バリウム担持量の影響}

Fig. 5 にバリウム担持量を $0 \sim 17 \mathrm{wt} \%$ の範囲で変化させたと きの $\mathrm{Ba} / \mathrm{Y}_{2} \mathrm{O}_{3}$ 触媒の $\mathrm{NO}$ 分解活性を示す。 $\mathrm{Y}_{2} \mathrm{O}_{3}$ のみではほとん

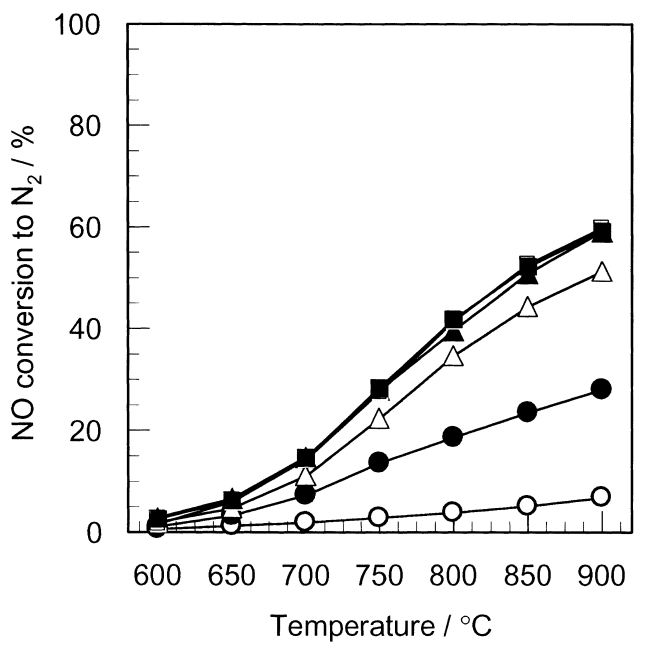

$\bigcirc: \mathrm{Y}_{2} \mathrm{O}_{3}, \mathrm{O}_{1} \mathrm{wt} \% \mathrm{Ba} / \mathrm{Y}_{2} \mathrm{O}_{3}, \triangle: 3 \mathrm{wt} \% \mathrm{Ba} / \mathrm{Y}_{2} \mathrm{O}_{3}, \boldsymbol{\Delta}: 5 \mathrm{wt} \%$ $\mathrm{Ba} / \mathrm{Y}_{2} \mathrm{O}_{3}, \square: 10.9 \mathrm{wt} \% \quad \mathrm{Ba} / \mathrm{Y}_{2} \mathrm{O}_{3}, \square: 17 \mathrm{wt} \% \quad \mathrm{Ba} / \mathrm{Y}_{2} \mathrm{O}_{3}$. Conditions: $\mathrm{NO}=1000 \mathrm{ppm}, W / F=0.5 \mathrm{~g} \cdot \mathrm{s} \cdot \mathrm{m}^{-3}$.

Fig. 5 Effect of Barium Content on the Catalytic Activity of $\mathrm{Ba} / \mathrm{Y}_{2} \mathrm{O}_{3}$ after $\mathrm{H}_{2}$ Reduction at $900^{\circ} \mathrm{C}$ for NO Decomposition

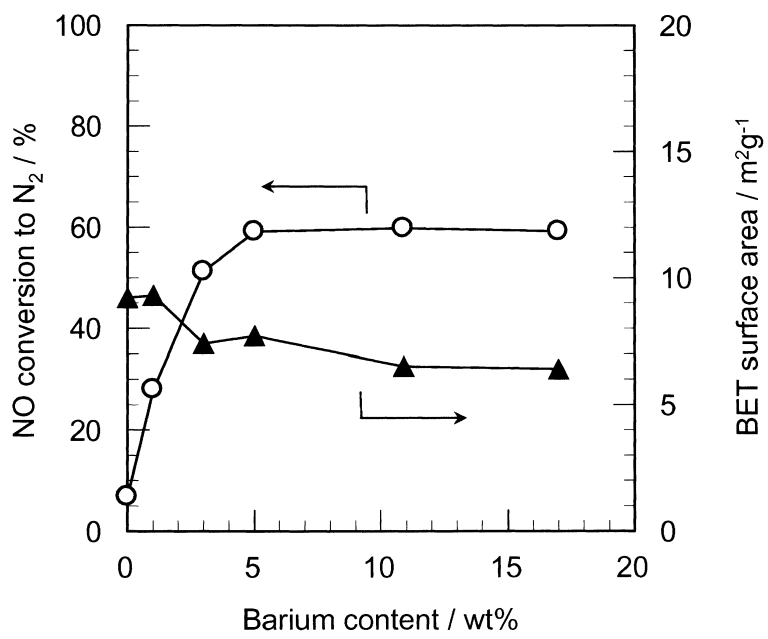

Fig. 6 Change in the BET Surface Area $(\mathbf{\Delta})$ and Conversion of $\mathrm{NO}$ to $\mathrm{N}_{2}$ at $900^{\circ} \mathrm{C}(\bigcirc)$ over $\mathrm{Ba} / \mathrm{Y}_{2} \mathrm{O}_{3}$ Treated with $\mathrm{H}_{2}$ at $900^{\circ} \mathrm{C}$ as a Function of Barium Content

どNO分解反応は進行しないが， $1 \mathrm{wt} \%$ のバリウムを担持する と NO分解活性は大きく向上し, NO転化率はバリウム担持量 が $5 \mathrm{wt} \%$ まで徐々に増加した。バリウム添加量を $5 \mathrm{wt} \%$ 以上に しても活性はそれ以上向上しなかった。

Fig. 6には $900^{\circ} \mathrm{C}$ での NO転化率と BET 比表面積のバリウム 担持量に対する変化を示す。上述のように NO転化率はバリウ ム添加量とともに増加し， $5 \mathrm{wt} \%$ 以上ではほぼ同じ NO転化率 が得られた。一方, $900^{\circ} \mathrm{C}$ で水素還元処理後のBET比表面積は バリウム担持量とともに減少する傾向が見られ，NO転化率と の相関性は見られなかった。Fig. 7 には $900^{\circ} \mathrm{C} て ゙ の ~ N O$ 転化率 


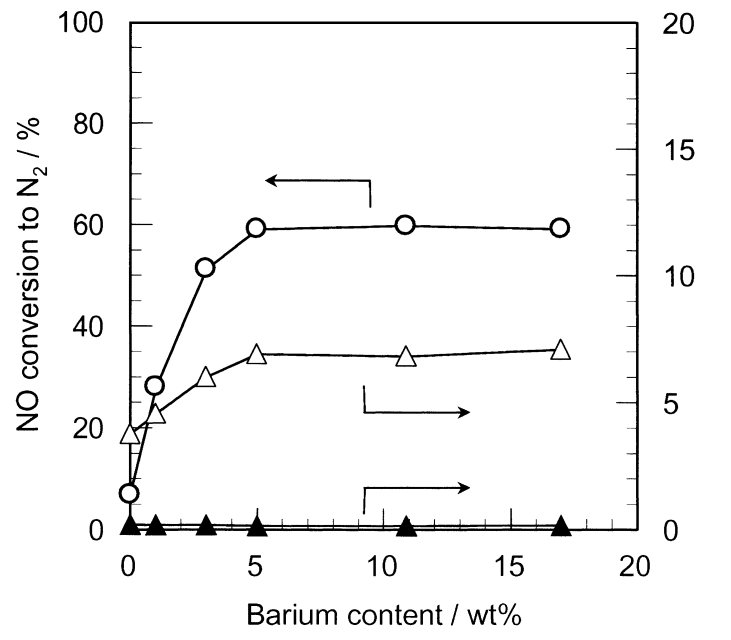

$\Delta$ : fresh catalyst. $\bigcirc, \triangle: 900^{\circ} \mathrm{C}-\mathrm{H}_{2}$ pretreated catalyst.

Fig. 7 Change in the Amount of NO Adsorption $(\boldsymbol{\Delta}, \triangle)$ and the Conversion of $\mathrm{NO}$ to $\mathrm{N}_{2}$ at $900^{\circ} \mathrm{C}(\mathrm{O})$ over $\mathrm{Ba} / \mathrm{Y}_{2} \mathrm{O}_{3}$ as a Function of Barium Content

とともにパルス法により求めた NO吸着量の測定結果を示す。 明らかにNO転化率と NO吸着量との間にはよい相関性が見ら れ，NO吸着点が NO分解反応に関与している可能性を示唆し ている。また，Fig. 7 には $900^{\circ} \mathrm{C}$ 還元処理を行っていない触媒 の NO吸着量も示すが, どのバリウム担持量の触媒においても NO吸着はほとんど起こらない。このことから，水素還元処理 により炭酸塩が分解し, NO吸着サイトが生成するものと考え られる。

\section{3. $\mathrm{Ba} / \mathrm{Y}_{2} \mathrm{O}_{3}$ 触媒上での1-ブテン異性化反応}

上述のようにNO吸着サイトがNO分解反応に何らかの形で 関与していることが示唆された。金属酸化物表面への NO吸着 は，多くの場合，亜硝酸イオン $\left(\mathrm{NO}_{2}^{-}{ }^{-}\right)$か硝酸イオン $\left(\mathrm{NO}_{3}{ }^{-}\right)$ の形で吸着することが知られており ${ }^{13)}$ ，塩基点が吸着サイトで あるものと考えられる。そこで，触媒表面の塩基特性を評価す るために酸塩基触媒反応のモデル反応である1-ブテン異性化反 応14)を行った。1-ブテン異性化反応により cis-2-ブテンと trans2-ブテンが生成するが，その生成比は使用する触媒により異な り，酸触媒では cis/trans 比が $1 \sim 2$, 塩基触媒では cis/trans 比は 20 程度の高い值となる ${ }^{14), 15)}$ 。本研究で行った $\mathrm{Ba} / \mathrm{Y}_{2} \mathrm{O}_{3}$ 触媒上で の1-ブテン異性化反応において，Fig. 8(A)に示すように cis/trans 比は8 12の值になり，本触媒上には塩基点が主に存 在していることが分かった。また，Fig. 8(A)から明らかなよ うに， cis/trans比はわずかではあるがバリウム担持量とともに 小さくなる傾向が見られた。これはバリウム担持量により塩基 性度が異なることを示唆しており，低いバリウム担持量の触媒 ほど，強い塩基点の割合が多いことが考えられる。

Fig. 8(B)に $900^{\circ} \mathrm{C}$ で水素還元処理を行った $\mathrm{Ba} / \mathrm{Y}_{2} \mathrm{O}_{3}$ 触媒上で の1-ブテン異性化反応の結果を示す。 $\mathrm{Y}_{2} \mathrm{O}_{3}$ 単独では異性化反 応はほとんど進行しなかったが，バリウムを担持することによ り反応活性は向上し，バリウム担持率が $10.9 \mathrm{wt} \%$ の時の最大

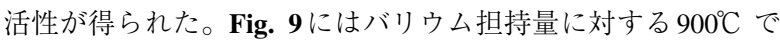
の NO転化率と 1-ブテン異性化活性の変化を示す。Fig. 9から

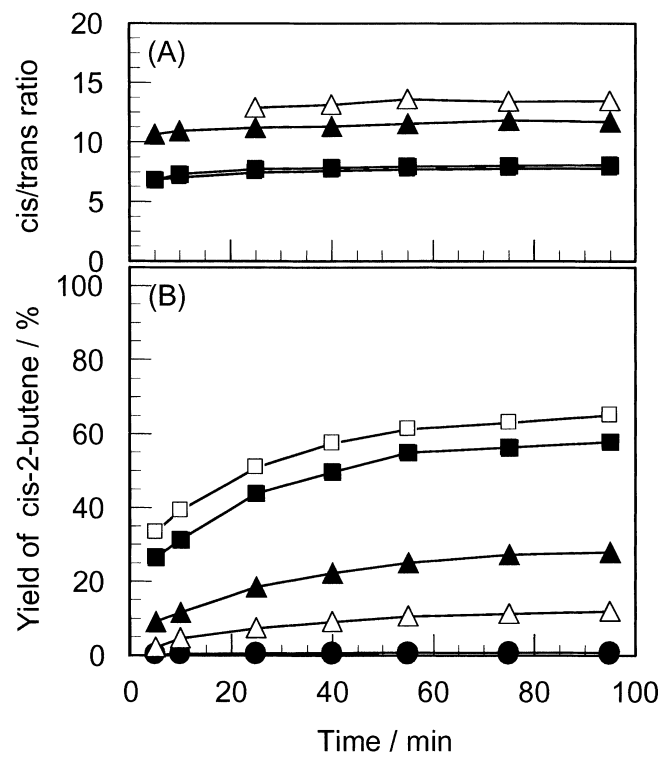

: $\mathrm{Y}_{2} \mathrm{O}_{3}, \mathrm{O}_{1} 1 \mathrm{wt} \% \mathrm{Ba} / \mathrm{Y}_{2} \mathrm{O}_{3}, \triangle: 3 \mathrm{wt} \% \mathrm{Ba} / \mathrm{Y}_{2} \mathrm{O}_{3}, \boldsymbol{\Delta}: 5 \mathrm{wt} \%$ $\mathrm{Ba} / \mathrm{Y}_{2} \mathrm{O}_{3}, \square: 10.9$ wt $\% \quad \mathrm{Ba} / \mathrm{Y}_{2} \mathrm{O}_{3}, \square: 17$ wt $\% \quad \mathrm{Ba} / \mathrm{Y}_{2} \mathrm{O}_{3}$ Conditions: initial pressure of 1-butene $=93 \mathrm{kPa}$, catalyst weight $=$ $0.03 \mathrm{~g}$, temperature $=0^{\circ} \mathrm{C}$

Fig. 8 Time Dependence of (A) cis/trans Ratio of 2-Butene and (B) Yield of cis-2-Butene for Isomerization of 1Butene over $\mathrm{Ba} / \mathrm{Y}_{2} \mathrm{O}_{3}$ with Different Barium Contents

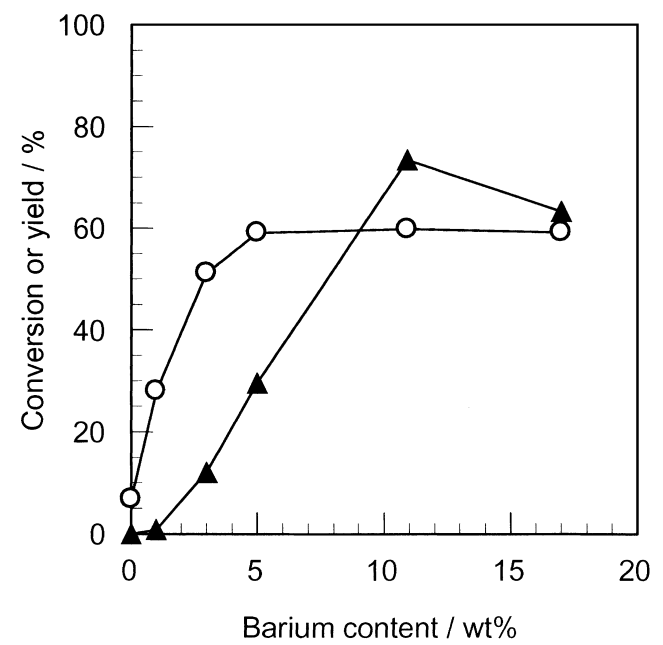

Fig. 9 Change in Yield of cis-2-Butene $(\mathbf{A})$ and Conversion of $\mathrm{NO}$ to $\mathrm{N}_{2}$ at $900^{\circ} \mathrm{C}(\bigcirc)$ over $\mathrm{Ba} / \mathrm{Y}_{2} \mathrm{O}_{3}$ Pretreated with $\mathrm{H}_{2}$ at $900^{\circ} \mathrm{C}$ as a Function of Barium Content

明らかなように，NO分解反応と1-ブテン異性化反応の活性の 間には比較的よい相関性が見られ，NO分解反応において塩基 点が重要な役割を担っていることが推定される。しかしながら, バリウム担持率に対する両反応活性の関係が完全に一致してい ないことから，単なる塩基性ではなく，塩基強度やNO分解反 応に特異的に作用する塩基点の存在など，解明しなければなら ない多くの要因が存在しているようである。 


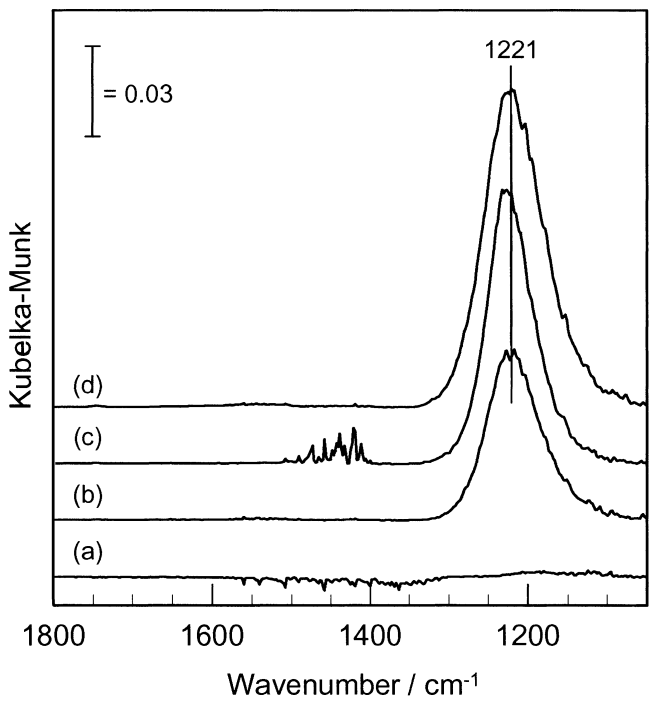

Fig. 10 Diffuse Reflectance FT-IR Spectra Recorded in Flowing $1000 \mathrm{ppm} \mathrm{NO} / \mathrm{He}$ over (a) $\mathrm{Y}_{2} \mathrm{O}_{3}$, (b) $5 \mathrm{wt} \%$ $\mathrm{Ba} / \mathrm{Y}_{2} \mathrm{O}_{3}$, (c) $10.9 \mathrm{wt} \% \quad \mathrm{Ba} / \mathrm{Y}_{2} \mathrm{O}_{3}$ and (d) $17 \mathrm{wt} \%$ $\mathrm{Ba} / \mathrm{Y}_{2} \mathrm{O}_{3}$ at $600^{\circ} \mathrm{C}$ for $1 \mathrm{~h}$

\subsection{NO分解反応における塩基点の役割}

我々はこれまでにアルカリやアルカリ土類を添加した酸化コ バルト触媒について反応速度論的な検討を行い，添加したアル カリやアルカリ土類上に吸着 $\mathrm{NO}_{2}{ }^{-}$種が生成し，これが中間体 として関与する反応機構を提案した7),16)。同様に，Xieら ${ }^{17)}$ は in-situ ラマン分光法を用いて, $\mathrm{Ba} / \mathrm{MgO}$ 上での $\mathrm{NO}$ 分解反応中に $\mathrm{Ba}-\mathrm{NO}_{2}$ の生成を観察し，これが中間体として作用する反応機 構を提案している。これらの反応機構は塩基点が反応活性点と して作用することを示唆しており，本研究で検討した $\mathrm{Ba} / \mathrm{Y}_{2} \mathrm{O}_{3}$ 触媒上での NO分解反応も同じ反応機構で進行していることが 推定される。

そこで, $\mathrm{Ba} / \mathrm{Y}_{2} \mathrm{O}_{3}$ 触媒上での $\mathrm{NO}$ 分解反応に扮ける塩基点の 役割を明らかにするために，FT-IRにより反応条件下での吸着 $\mathrm{NO}_{x}$ 種の観察を行った。Fig. 10 に $600^{\circ} \mathrm{C}$ で測定したFT-IR スペ クトルを示す。NO分解活性の低い $\mathrm{Y}_{2} \mathrm{O}_{3}$ 単独（Fig. 10(a)）で は吸着 $\mathrm{NO}_{x}$ 種の生成は認められなかったが, $\mathrm{Ba} / \mathrm{Y}_{2} \mathrm{O}_{3}$ では 1221 $\mathrm{cm}^{-1}$ 付近に吸着 $\mathrm{NO}_{2}{ }^{-}$種に帰属13) できるピークが見られた。バ リウムなどの塩基点上での NO吸着挙動に関しては多くの報告 があり, $\mathrm{NO}$ が $\mathrm{BaO}$ の塩基性格子酸素と相互作用することによ り, 酸素イオンから $\mathrm{NO}$ 一電子の移動が起こり, $\mathrm{NO}_{2}{ }^{-}$P $\mathrm{NO}_{3}{ }^{-}$ が生成すると考えられている ${ }^{18), 199}$ 。本研究においても $\mathrm{NO}_{2}{ }^{-}$-種 は同様の機構で起こっていると考えられ, $\mathrm{NO}_{2}{ }^{-}$種の生成には バリウムの存在，つまり塩基点が必要であることが分かった。
また, 吸着 $\mathrm{NO}_{2}$-種のピーク強度はバリウム担持量とともに増 大しており，これは塩基点の数抢よび NO分解活性（Fig. 9) とよく一致している。以上の結果より, $\mathrm{NO}$ 分解反応に抢ける 塩基点の役割は反応中間体である吸着 $\mathrm{NO}_{2}{ }^{-}$種の生成を促進す ることにあると考えられる。

\section{4. まとめ}

$\mathrm{NO}$ 直接分解反応は塩基性酸化物である担持アルカリ土類酸 化物触媒上で進行することを見出した。検討した触媒の中で $\mathrm{Ba} / \mathrm{Y}_{2} \mathrm{O}_{3}$ が最も高い $\mathrm{NO}$ 分解活性を示した。 $\mathrm{Ba} / \mathrm{Y}_{2} \mathrm{O}_{3}$ の $\mathrm{NO}$ 分解 活性と NO吸着量および1-ブテン異性化活性との間に比較的よ い相関性が認められ，触媒の塩基点が NO分解反応において反 応中間体である吸着 $\mathrm{NO}_{2}$-種の生成に対して重要な役割を担っ ていることが考えられた。

\section{References}

1) Amirnazmi, A., Benson, J. E., Boudart, M., J. Catal., 30, 55 (1973).

2) Winter, E. R. S., J. Catal., 22, 158 (1971).

3) Uchijima, T., Hyomen, 18, 132 (1980).

4) Iwamoto, M., Furukawa, H., Mine, Y., Uemura, F., Mikuriya, S., Kagawa, S., J. Chem. Soc., Chem. Commun., 1272 (1986).

5) Boreskov, G. K., Discuss. Faraday Soc., 41, 263 (1966).

6) Haneda, M., Kintaichi, Y., Bion, N., Hamada, H., Appl. Catal. B: Environ., 46, 473 (2003).

7) Haneda, M., Tsuboi, G., Nagao, Y., Kintaichi, Y., Hamada, H., Catal. Lett., 97, 145 (2004).

8) Meubus, P., J. Electrochem. Soc., 124, 49 (1977).

9) Zhang, X. K., Walters, A. B., Vannice, M. A., J. Catal., 155, 290 (1995)

10) Vannice, M. A., Walters, A. B., Zhang, X., J. Catal., 159, 119 (1996).

11) Xie, S., Rosynek, M. P., Lunsford, J. H., J. Catal., 188, 24 (1999).

12) Huang, S.-J., Walters, A. B., Vannice, M. A., J. Catal., 192, 29 (2000).

13) Hadjiivanov, K. I., Catal. Rev.-Sci. Eng., 42, 71 (2000).

14) Catalysis Society of Japan, "Characterization of Solid Catalysts,” Kodansha Scientific, Tokyo (1985), p. 180-184. 触媒学会編, “固体触媒のキャラクタリゼーション,”講談 社サイエンティフィク, 東京 (1985), p. 180-184.

15) Kabashima, H., Tsuji, H., Nakata, S., Tanaka, Y., Hattori, H., Appl. Catal. A: General, 194, 227 (2000).

16) Haneda, M., Kintaichi, Y., Hamada, H., Appl. Catal. B: Environ., in press.

17) Xie, S., Mestl, G., Rosynek, M. P., Lunsford, J. H., J. Am. Chem. Soc., 119, 10186 (1997).

18) Broqvist, P., Panas, I., Fridell, E., Persson, H., J. Phys. Chem. $B, \mathbf{1 0 6}, 137$ (2002).

19) Fanson, P. T., Horton, M. R., Delgass, W. N., Lauterbach, J., Appl. Catal. B: Environ., 46, 393 (2003). 
要旨

\title{
担持アルカリ土類酸化物触媒上での NO 直接分解反応
}

\author{
坪井 吾朗 ${ }^{\dagger 2)}$, 羽田 政明 ${ }^{\dagger 1)}$, 長尾 幸徳 ${ }^{\dagger 2)}$, 金田一 嘉昭 ${ }^{\dagger 1)}$, 浜田 秀昭 ${ }^{\dagger 1)}$ \\ †1) 産業技術総合研究所 環境化学技術研究部門，305-8565 茨城県つくば市東 1-1-1つくば中央第 5 \\ †2) 東京理科大学, 278-8510 千葉県野田市山崎 2641
}

担持アルカリ土類酸化物触媒の NO 分解活性は担体に大きく 依存し, $\mathrm{Y}_{2} \mathrm{O}_{3}$ が最も効果的な担体であった。また, 検討した 担持アルカリ土類酸化物触媒の中で $\mathrm{Ba} / \mathrm{Y}_{2} \mathrm{O}_{3}$ が最も高い活性を 示し, $\mathrm{NO}$ 分解活性は $\mathrm{Ba} / \mathrm{Y}_{2} \mathrm{O}_{3}>\mathrm{Sr} / \mathrm{Y}_{2} \mathrm{O}_{3}>\mathrm{Ca} / \mathrm{Y}_{2} \mathrm{O}_{3}>\mathrm{Mg} / \mathrm{Y}_{2} \mathrm{O}_{3} \sim$ $\mathrm{Y}_{2} \mathrm{O}_{3}$ の順で低下した。 $\mathrm{Ba} / \mathrm{Y}_{2} \mathrm{O}_{3}$ の $900^{\circ} \mathrm{C}$ での $\mathrm{NO}$ 分解活性は反 応時間とともに徐々に向上する傾向が認められ，これは反応中 に炭酸バリウムが酸化バリウムに分解するためであることが分 かった。炭酸バリウムの分解には $900^{\circ} \mathrm{C}$ での水素還元処理が効 果的であった。 $\mathrm{Ba} / \mathrm{Y}_{2} \mathrm{O}_{3}$ の $\mathrm{NO}$ 分解活性はバリウム担持量が 5 $\mathrm{wt} \%$ まで徐々に増加し, それ以上の担持量では活性の向上は 見られなかった。 $900^{\circ} \mathrm{C}$ での水素還元処理により $\mathrm{Ba} / \mathrm{Y}_{2} \mathrm{O}_{3}$ 上に $\mathrm{NO}$ 吸着サイトが生成し, NO分解活性と NO吸着量との間によ い相関性が認められた。 $\mathrm{Ba} / \mathrm{Y}_{2} \mathrm{O}_{3}$ 触媒の塩基性を調べるために 1-ブテン異性化活性を評価した結果, NO転化率との間に比較 的よい相関性が認められ, 塩基点が NO分解反応の中間体であ る吸着 $\mathrm{NO}_{2}{ }^{-}$種の生成に関与していることがFT-IR 測定より推定 された。 